\title{
OCTAVIO PAZ Y JORGE GUILLÉN: DEL AMOR Y LOS DIOSES HINDÚES
}

\author{
José María BALCELLS \\ Universidad de León \\ jmbald@unileon.es
}

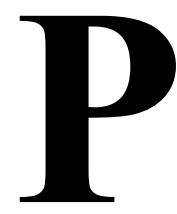
az: Shiva, símbolo del amor profundo

A modo de preámbulo al comentario del poema de Octavio Paz en el cual vamos a centrarnos, recordaré el interés espiritual hacia el hinduismo que distinguió a este escritor mexicano, que llega a vivir en la India en dos períodos de su vida. A principios de 1952, en efecto, estuvo unos meses en dicho país en misión diplomática, tras haber ocupado el empleo de tercer secretario de la Embajada mexicana en París. Pero pronto dejaría Delhi para prestar servicios, durante cinco meses, y a título de encargado de negocios, en la Embajada de México en Japón, reciente en ese país aún la ocupación estadounidense. El segundo período en la India ya fue en calidad de embajador de México, embajada que conllevaba ser también embajador en Afganistán. Esta etapa comenzó en otoño de 1962, y abarcaría media docena de años, finalizando con su renuncia al cargo por los disturbios saldados con muertes de estudiantes en la plaza de Tlatelolco, en Ciudad de México, y como consecuencia de la eclosión reivindicativa del mayo de 1968. Paz daba ejemplo, renunciando a ese alto cargo, de independencia intelectual y de compromiso con el respeto a la dignidad humana (Vizoso, 1998: 60). En 1966, siete años después de divorciarse de la escritora mexicana Elena Garro, en el jardín de su residencia en Delhi se había casado con Marie José Tramini, su segunda esposa, de nacionalidad francesa y originaria de la isla de Córcega.

De quince textos poéticos consta Hacia el comienzo, libro organizado conforme a patrones rítmicos no preconcebidos. Distintos pasajes de la obra se refieren o inspiran en lugares de París, de Afganistán, de Pakistán y de la India. La compuso Octavio Paz en los días en que el ejército estadounidense, en tiempos de la presidencia de Lyndon B. Johnson, intervino militarmente en República Dominicana, según él mismo indicó sin precisar fechas concretas (Paz, 1998: 178). Con la excusa de proteger de las convulsiones político-militares en ese país caribeño a los ciudadanos de los Estados Unidos que en él residían, pero con el fin estratégico de impedir allí una segunda Cuba comunista, aquella acción militar se produjo desde fines de abril de 1965, prolongándose hasta 
septiembre de 1966, y por tanto hay que situar la confección de Hacia el comienzo en los meses comprendidos entre los indicados.

La primera de las composiciones de este conjunto, de considerable extensión, al igual que la última, es una de las más significativas. En ella se nombra a las divinidades del hinduismo Shiva y Parvati, en las que se concentrará el penúltimo poema, «Domingo en la isla de Elefanta». En dicho texto inicial, que lleva por título «Viento entero», se repite una afirmación clave en el decurso de estos versos, la de «El presente es perpetuo». Este aserto ha de relacionarse con la idea del escritor mexicano según la cual la cosmovisión hindú no solo obvia la historia, sino que «aniquila el devenir -y al mismo tiempo la idea de progreso-» (Durán, 1982: 251-252). Esta clave cosmovisionaria 'sustenta la visión de ambas divinidades amándose perdurablemente «En el pico del mundo», expresión sobre la que el poeta aclarará en una nota que hace referencia a una cumbre concreta que es la residencia sagrada del dios: «En el pico del mundo: el gran dios Shiva (Mahadeva) y Parvati, su consorte, viven en el monte Kalaisa, en los Himalayas» (Ibídem). He aquí las tres líneas concernidas:

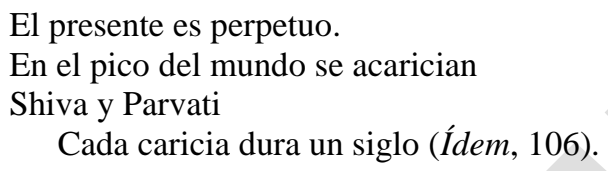

Un diseño de contorno muy discrecional presenta en su textura y en su rítmica el poema «Domingo en la isla Elefanta», distribuido en dos secciones: un encabezamiento titulado «Imprecación», y una parte segunda y nuclear a la que su autor puso el título de «Invocación». Los nueve versos primeros tienen, en consonancia con su titulación, carácter imprecatorio. Son reprendidas en ellos con extraordinaria dureza dos clases de conductas irrespetuosas con sendas estatuas de Shiva y Parvati que se hallan en la isla antedicha. El hablante censura, de un lado, a unos genéricos musulmanes y portugueses que desfiguraron esas efigies, y de otro a tantísimas personas como acuden al lugar para hacer una de esas excursiones dominicales campestres, denominadas picnic, en las que grupos de individuos, sentados, posan en el suelo, sobre algún mantel, los manjares, la bebida y en su caso los utensilios, lo que en la mayoría de los casos se traduce, y así lo delata el poeta, en basura no recogida, y que será alimento de cuervos y de perros.

A modo de contextualización de esa agria crítica de Octavio Paz, señalaremos que Elefanta está situada a tan solo nueve kilómetros de la populosa ciudad portuaria de Bombay, en la costa oeste del subcontinente indio, y una de las urbes más pobladas del mundo. Los portugueses le dieron ese nombre a causa de la proliferación de elefantes que allí habitaban en el pasado. Es una isla de pescadores en la que se encuentran varias grutas con templos y efigies de divinidades hinduistas, destacando una estatua colosal de Shiva. No pocos fieles acuden a ese lugar para hacer ofrendas florales a sus dioses. Dada la cercanía a Bombay, las visitas de turismo cultural a la zona también menudean. Sin embargo, y en contrapunto grosero con ambos tipos de respetuosos viajeros, son multitud las gentes que van a la isla con el propósito exclusivo de realizar una de esas acostumbradas comidas festivas que no demuestran la más mínima consideración con el medio ambiente ni con el 
significado sacro del enclave. Contra esa conducta se alza, condenatoria, la voz que habla en el poema.

Dos condenas poético-religiosas se dictan a continuación a los participantes en el atropello del lugar sagrado. Una es la hiperbólica de «renacer cien veces/ en un muladar» Bien distinta es la condena a musulmanes y a portugueses, aunque no menos pavorosa e incluso atroz: se les haría una talla en carne viva para que viviesen en un imaginario «infierno de los mutiladores de estatuas». En ambas condenas, aunque con más evidencia en la primera, el dicente asume la creencia hinduista en distintas clases de reencarnación: si la vida fue vivida con dignidad, el individuo merecerá un reencarnarse favorable, pero una mala conducta mientras se vive, y son ejemplo las señaladas, va a conllevar reencarnarse en seres de condición más baja que la anterior. País de grandes contrastes, la denunciada de desmerecer la sacralidad que representan esas estatuas de grandes dioses con tan indignos comportamientos humanos es una de las contradicciones de la India que se muestran en este poema de Hacia el comienzo (Hernández, 2011: 2).

El título de la sección segunda responde bien a su contenido, porque el hablante se dirige a las dos divinidades nombradas, Shiva y Parvati, para manifestarles lo que ellas significan para los seres humanos, para él mismo y para, según sus palabras, «la mujer que es mi mujer» (Ídem, 126), en alusión biográfica a Marie José, con quien se casó en la India, según adelantábamos. En el tramo final del texto, nada de índole material se pide a esos dioses, sino que se les hace una demanda poética, como referiré después.

Pero antes de proseguir me parecen oportunas unas pocas líneas para recordar unos rasgos mínimos y diferenciales caracterizadores de Shiva. Este dios es uno de los tres que constituyen el Trimurti, o Trinidad, en la religión indostánica, deidades las tres que son manifestaciones de los infinitos ciclos naturales de generación y corrupción de las cosas. Las otras dos son Brahma y Vishnu.

Brahma detenta el rol de dios creador. A él mismo se le atribuye un ciclo vital, aunque de varios millones de años, y cumplido este ciclo sucede una fase de un siglo con anterioridad a que el ciclo se inicie otra vez con un nuevo Brahma creando un nuevo universo (Pemberton, 2015: 146). Es, de las tres divinidades, la menos adorada, sin duda por concebírsela como un dios abstracto e inaccesible, y al que solo osan acercarse quienes se dedican expresamente al estudio de los textos sagrados. Sin embargo, la tradición hindú identifica a Brahma con el mundo, porque Brahma no solo lo crea, sino que es el mundo mismo: el mundo es una manifestación suya. Brahma es el alma del universo y las almas individuales son expresiones separadas de sí mismo, pero remitiendo a él como las chispas remiten al fuego. Esa concepción unitaria no suele ser considerada por el común sentir de la gente, sino por pensadores y poetas.

A diferencia de Brahma, a Shiva y a Vishnu los creyentes los sienten cercanos, considerándolos muy influyentes en sus vidas. Vishnu es el conservador de las cosas, el que las preserva. Shiva es el dios destructor por antonomasia, aunque también posee la facultad de volver a crear cuanto ha destruido. Destruye el mundo al término de cada ciclo universal, pero lo hace para que se produzca 
un mundo nuevo, previo al cual danza, de ahí que en muchas representaciones suyas aparezca danzando. Si su sello más determinante es el de destruir, en realidad destruye para que pueda volverse a crear, significando su nombre el Misericordioso.

«Invocación», sección segunda del poema «Domingo en la isla de Elefanta», nos permite acercarnos a otros rasgos de ese dios. Shiva tiene un tercer ojo, vertical, en su frente, y mediante él reduce el deseo a cenizas. Dispone de cuatro brazos, al igual que Vishnu, brazos cuyo simbolismo se explicita en el poema de Octavio Paz al recordarle que sus «cuatro brazos son cuatro ríos, /cuatro surtidores» (Paz, 1998: 125), asociación metafórica acuática que de algún modo la coloreada iconografía habitual en azul invita a sugerir.

Respecto a las esposas de Shiva, el escritor levantino Vicente Blasco Ibáñez, en el libro tercero de su narración de viajes La vuelta al mundo de un novelista, publicada en 1924, se refirió a ellas por orden cronológico, y ponderando la ambivalencia que compartieron esas tres formas distintas adoptadas por la consorte del dios, llamada Saraswati, diosa de las artes y del aprendizaje, y a la que se atribuye la invención del sánscrito, de ahí que haya imágenes suyas en centros docentes y en librerías. Esos son los tres aspectos suyos:

Kali (la Negra), Durga (la Inaccesible) y Parvati (la Hija de la Montaña), resultan también divinidades complejas y contradictorias, unas veces amorosas y otras pidiendo sangre y muerte (Blasco Ibáñez, 1967: III, 632).

La esposa originaria de Shiva es Sati, denominada Kali en el pasaje recién citado, pero se reencarnará en Parvati, cuya estatua suele ser colocada junto a la de Shiva. La significación originaria de ese nombre es, como leíamos en la cita, la de «Hija de la montaña», pues su nacimiento se produjo en el Himalaya. Según el relato más famoso relativo a Shiva, éste se recluyó en esa cordillera para experimentar enseñanzas espirituales viviendo una vida monástica. En un principio rehuía la seducción de Parvati, pero luego iba a entrar el deseo en él hasta amarla, y tras haberle restituido el deseo a ella misma, la cual también se había entregado a la vida solitaria y austera por entender que así lograría que la amase (Nivedita; Coomaraswamy, 1995: 269).

Siendo esta pareja dos dioses del hinduismo, en el poema se les dice que, en realidad, no se les adora como tales, sino como imágenes, pero no en el sentido de que sean meros iconos, aunque sagrados, sino como imágenes de la divinidad que anida en los seres humanos. Ellos son ya lo que el hombre ha de lograr ser mediante sus actos, porque ése es su ineludible destino, el de que nadie puede ser hasta que «pague la condena del quehacer» (Paz, 1998: 125).

En los versos centrales de «Invocación» solo es invocado Shiva, no Parvati. En ellos, como recordábamos antes, los cuatro brazos del dios hindú eran leídos como ríos, como surtidores, pero añadiéndose a continuación tres líneas más en las que importa detenernos:

Todo tu ser es una fuente

y en ella se baña la linda Parvati,

en ella se mece como una barca graciosa (Ídem, 125-126). 
Los dos, Shiva y Parvati, forman un matrimonio, es verdad, pero es ella quien devuelve a su marido hacia la realidad amorosa cuando él se inclina hacia el ascetismo y hacia romper su relación con el mundo (Wilkinson, 2008: 309). En el poema no están los cónyuges en el mismo plano, porque la esposa se baña en un manantial que resulta ser su propio marido. Si los ríos y surtidores y la fuente habían sido asociados a Shiva, y Parvati era vista como una barca que se mecía en el agua, luego el hablante lírico identificará con el mar los labios de él y los brazos de ella, remitiendo, respectivamente, al pálpito marino y al tono dorado acuático reflejando el astro solar. Así lo expresó el poeta:

El mar palpita bajo el sol:

son los gruesos labios de Shiva que sonríe;

el mar es una larga llamarada:

son los pasos de Parvati sobre las aguas (Paz, 1998: 126).

Y en este punto es cuando se produce la petición a la que arriba aludíamos, y cuyo motivo ahora comprendemos. Shiva y Parvati representan al hombre y a la mujer, y su unión de amor eterniza el presente. Un vivir juntos, pero la una en el otro, ella en él, es lo único que se pide que les sea concedido al hablante y a su compañera, a fin de reproducir el círculo amoroso constante y sucesivo del mundo. En esa petición se juntan los dos factores que el poeta mexicano siempre consideró más revolucionarios en la vida: el amor y la poesía, pero vividos en toda su profundidad. En la fusión de sus vivencias con el simbolismo de esas dos divinidades nos mostraba Octavio Paz «la estructura esencial de su pensamiento y la transposición de ésta en el modo mítico» (Philips, 1976: 69).

\section{Krishna y Prajapati en Jorge Guillén}

Krishna, según la sección sexta del poema védico hindú Mahabharata, texto anónimo del siglo III a. C. atribuido fictivamente a Vyasa (Renou, 1951: 16), sección llamada Bhagavad Gita, es la octava de las diez encarnaciones de Vishnu. Influido por el pensamiento budista, el Bhagavad Gita, que significa «Canción del adorable», constituye uno de los escritos fundamentales del hinduismo, porque en él se exponen sus conceptos básicos, siendo una de sus claves más sustantivas la de concebir el mundo como «maya», como una ilusión.

A modo de recordatorio, indicaré que el Mahabharata se denomina así porque se refiere a la gran historia de la saga de los Bharatas. En el poema se canta la lucha por el poder de dos ramas de esa familia, la de los Pandavas y la de los Kauravas. Tanto la una como la otra descienden del rey Bharata, nombre que constituye una derivación del originario de la India. En esta obra aparecen numerosos personajes, con el propósito de representar la variedad de las experiencias humanas, desde las de la guerra hasta las del amor. En consecuencia, tan dilatada composición abarca un amplísimo espectro de asuntos, desde los personales a los de índole política, desde los relativos a la ética y a la moral hasta los de carácter religioso. 
En la antecitada sección sexta del Mahabharata, el Bhagavad Gita, se cantan acontecimientos sucedidos con anterioridad a la gran batalla que van a entablar los Pandavas y los Kauravas. Uno de los miembros de la primera de estas familias, el príncipe Arjuna, está horrorizado ante la inminencia del enfrentamiento armado, y le confiesa al conductor de su carro de combate, Khrisna, que no puede participar en esa guerra. Esta situación le permitirá a éste exponerle el concepto de dharma, o actitud y función que debe adoptar cada persona de acuerdo con su sino. También le enseña que hay tres modos de unirse a Dios y a la verdad: la devoción religiosa, el conocimiento y las acciones comprometidas. Arjuna asume esa enseñanza, y parte al combate convencido de que, al guerrear, estará favoreciendo que el bien se imponga sobre el mal (Wilkinson, 2008: 168 y ss.).

El dios Krishna se había encarnado en Rama en su encarnación anterior, su séptimo avatar, de acuerdo con el otro poema épico del hinduismo, Ramayana, Gesta o Viaje de Rama, atribuido a Valmiki, escritor del siglo III a. de C. La tarea de este autor habría sido la de «réunir les éléments épars de la tradition orale et de les combiner en une composition semisavante» (Renou, 1951: 19), pues esta obra no pertenece a los textos revelados por la divinidad, sino a los transmitidos a través de la tradición.

Recordemos sucintamente que esta epopeya es bastante más corta que la anterior, aun cuando cuenta nada menos que con unos 24.000 versos. En ella se narra cómo Sita, nombre de la esposa del príncipe Rama que se corresponde con este avatar de Krishna, cae en poder del monstruo demoníaco Ravana. Sin embargo, Rama logrará rescatarla con la ayuda del dios mono Hanuman, una deidad que no aparece en los antiguos textos védicos, sino que va ligada a la historia de Rama, nombre que significa El Placentero.

En el Gita Govinda, poema pastoral escrito hacia 1180 por Jayadeva, compositor áulico de himnos hindúes, es visto Krishna como dios pastor, toda vez que Govinda fue el nombre adoptado por él al dedicarse al pastoreo. Ahí se canta su relación amorosa con una vaquera, Radha, en cantos que mutuamente se dedican los amantes. Una confidente es un tercer personaje en esta obra, en la que asimismo aparecen multitud de pastorcillas.

Gita Govinda está estructurado en doce cantos y veinticuatro cantilenas distribuidas en número desigual en esos cantos. El primero y el séptimo son los que contienen más, cuatro cada uno. El que hace once es el único con tres. Los restantes comprenden una o dos. Es ese un poema épico, a la vez que místico, pues esa hímnica puede interpretarse como una mística del alma humana inflamada de amor divinal.

Dos de sus momentos inspiraron sendas composiciones de Jorge Guillén que, consecuentemente, son de índole erótica, y que se integran en el conjunto Homenaje. Reunión de vidas, editado en Milán, en 1967. La integración de ese par de textos en dicho libro resulta bien coherente con los asuntos y el sentido del mismo. Porque se trata de poemas de amor y ese sentimiento es el que constituye el núcleo de Homenaje, donde el poeta vallisoletano recreó el sentir amoroso desde diversas perspectivas, y a partir de lo que expresaron distintos autores en pasajes concretos. 
Amén de esa coherencia temática de fondo, el título Homenaje. Reunión de vidas señala otra, la de que en la mayor parte del libro se rinde tributo de admiración a creaciones literarias que motivaron a Guillén y que pertenecen a diferentes literaturas, de ahí que la obra se encabece con la dedicatoria «A todas las musas». Evidentemente no son todas las musas ni todas las literaturas posibles las que se explicitan en la obra, sino una porción representativa de las letras occidentales de distintos siglos y de varios países, y en un elenco en el que los autores y textos españoles tienen predominio. Las letras asiáticas las representan un poema pretextado por un asunto clave, el del río, en la obra del poeta chino Po Chu-I, y asimismo las dos composiciones inspiradas en sendos pasajes líricos del Gita Govinda de Jayadeva.

Los poemas situados al comienzo de Homenaje llevan, por encima de su título, el de la obra o del autor que los inspiró, precedido de la expresión "Al margen...», de lo que es ejemplo el sobretítulo de «Al margen del Gita Govinda». Y debemos añadir que varias composiciones no antecedidas por dicha expresión la pudieran haber llevado, porque revisten características homologables a las de los que la llevan. La expresión «al margen» podría haberse referido a comentarios, a anotaciones a propósito de una obra, escritos o no en los márgenes de la misma. Pero en este libro dicha expresión puede equivaler a glosa poética, y no separada, sino inserta en el texto guilleniano, siendo a la vez germen de sus versos.

En Homenaje. Reunión de vidas se plasma la convicción de que el lector asume lo expresado en el verso al revivirlo. En su virtud, el poeta realizó esta obra mostrando la génesis de la misma en algunas de las lecturas de las que quiso ahí acordarse como lector, y a las que quiso homenajear como poeta. Y el Gita Govinda está entre las creaciones que le brindaron momentos vitales y poéticos que hizo suyos recreándolos.

El lapso en que el poeta los creó está comprendido entre los días 14 y 16 de abril de 1964 y el 17 de julio de 1965. Y los lugares en los que fue tejiendo y redondeando ambos textos serían americanos, en concreto caribeños y estadounidenses, y europeos, más exactamente italianos (Roma y Florencia) (Ídem, 1501). Encauzadas ambas composiciones en ritmo estrófico, la primera de ellas, «Al margen del Gita Govinda. Sotobosque», fue formulada como cuarteta en la que se combinan versos de 11 y de 7 sílabas, los primeros en las líneas impares. La segunda es una arromanzada décima octosilábica.

El estímulo que incentivó la creación de la cuarteta decía tan solo: «y sobre un lecho de ramillas jóvenes...», texto descriptivo que remitiría al canto viii $(6,4)$, al menos en la versión utilizada por Jorge Guillén. Apunte lírico tan leve como sugeridor despertaría en el poeta español imágenes de una escena en la que la calidez erótica late al unísono como señal de un amor vívido, dejando que floten en el aire estas palabras: «Tu nombre es sol, y mío». Con ellas se pone fin a un poema en el que el amor se manifestó, en contraste con la luminosidad solar, en la penumbra del ramaje, como se colige de las líneas que preceden a la recién referida, y que acaban con la constatación de un «Amo. Amas» coincidente con aquel título, «Amo, amas», que antepuso Rubén Darío al poema XXX de Cantos de vida y esperanza: 
Amor. Aún calor entre las ramas del sotobosque umbrío.

Y late la penumbra. Amo. Amas (Ídem, 38).

La décima «Dichosa llegada» se origina en la cita del Gita Govinda «un gozo grave en el rostro y amor en el corazón», del canto onceno $(22,1)$ de ese poema indio, lugar textual donde se poetiza cómo los amantes se han engalanado para su encuentro en un lecho de hojas en el seno de una cabaña. A ella van encaminándose desde un sitio distinto, pensando el uno en el otro y, una vez en el interior, ella capta las vivencias amorosas del corazón de su amado, cuyo semblante reflejaba una alegría tamizada de graveza. Y enseguida se entregan a los placeres de los juegos amorosos.

En los versos guillenianos se plasma, como se declara en el título, el regreso del amado a la vista y abrazos de la amada, un retorno dichoso a la mujer tan bella que le aguarda para una nueva entrega amorosa, no desde la ceguera pasional, sino desde la clarividencia lúcida. Son remarcables en el texto las precisas palabras que conllevan sugerencias eróticas susceptibles de leerse a un tiempo como sexuales y como sicológicas y metafísicas, así cuando el poeta se refiere a «placer extremo», y a «rendición feliz»y se redondea la décima con dos versos en los que describe el hablante su sensación erótica a la mujer que ama: «Y se abisma en ti mi amor,/ luz del ímpetu no ciego» (Ibídem).

En Y otros poemas, conjunto que se publicó en Buenos Aires en 1973, a cargo del sello Muchnik editores, incluyó Jorge Guillén un poema, «Creador y creación», que va a ser objeto de nuestro comentario por su ligamen con la mítica hindú. Pero antes, y al igual que hicimos a propósito de Homenaje. Reunión de vidas, esbozaremos un apunte sobre este libro de poesía que no iba a ser el último en la bibliografía lírica guilleniana, concluida en 1981 con la entrega de Final.

El título $Y$ otros poemas comienza con una conjunción unitiva que podría comportar varias connotaciones. De un lado, este vocablo conectivo iría apuntando al término de la obra poética de Guillén. De otro, indicaría el enlace de este libro con el anterior más inmediato. Y ciertamente entre estos poemas hay varios que representan una continuidad con Homenaje. Reunión de vidas, siendo muy explícitas al respecto titulaciones como las de «Homenaje a Rimbaud», «Al margen de Boccaccio», «Al margen de Valèry» $\mathrm{y}$ «Al margen de Aire nuestro». Pero además la primacía de esa cópula señala no solo la conexión con sus obras precedentes, «but also with the last-published “Serie”, Final (1981)» (Yudin, 1991: 91).

En $Y$ otros poemas la temática amorosa no tiene prevalencia, porque hay otros asuntos que enfatiza el poeta, destacando entre ellos el de la creación, en sus vertientes de creación del cosmos y de otras creaciones, y sobremanera de las literarias. El poema «Creador y creación» se inscribe en el tejido de la obra siendo uno de los que ilustran el que a juicio nuestro podría ser el núcleo central de la misma y conjuntándose con otros textos que cooperan en enriquecer su significación porque aportan perspectivas que la complementan. En su virtud, estimamos pertinente anotar breves comentarios a vueltas de las aludidas composiciones con anterioridad a adentrarnos en nuestra lectura de «Creador y creación». 
Bien adentrados en $Y$ otros poemas, nos encontramos un texto en el que se contienen anotaciones valiosas para el entendimiento del asunto relativo a problemáticas en torno al concepto de creación. Se alude al poema, repartido en tres momentos, que lleva por título «Taller». En él, y en su parte tercera, Jorge Guillén invita a que sean considerados los orígenes de las cosas, y menciona varios puntos que cabría considerar, como son «El dios, el ser, el átomo, la fuerza/ más allá siempre de la absurda nada» (Ídem, 829). Al lector que tenga presente esta invitación no podrá sorprenderle que en el libro se recojan poemas como «Átomo», o como «Impulso hacia forma», en el que un desbordamiento del río Arno hace pensar al dicente en la creadora fuerza genesíaca de la naturaleza. Tampoco le sorprenderán otras composiciones que convergen con el pretexto de la creación de las cosas como «Agentes o Agente», donde se alude a una proliferación de creaciones, pues la imaginación habría sido la que creó el mundo y sigue creándolo. Y los poetas, en tanto que creadores que se valen de la imaginación, no solo crean su obra, sino que a su través también crean continuadamente el mundo. Anoto además que uno de los textos, aun cuando no ha de conectarse de manera directa con «Creador y creación», finaliza refiriéndose a la incógnita que supone el cosmos, habiéndolo titulado el escritor de manera tal que justifica el que abordase la creación desde el hinduismo. El título dice así: «Naturaleza como fábula».

«Creador y creación» reviste una extraordinaria singularidad en su asunto dentro de la extensa secuencia de la entera historia de la poesía española, e incluso de la hispánica. En el decurso secular de tales creaciones, en efecto, se escribieron diversas cosmogonías, plasmaciones poéticas acerca de cómo pudo haber sido creado el cosmos. Y bien excusado sería añadir que la cosmovisión que en absoluto predomina en las mismas es la cristiana.En el siglo XIX se compuso, sin embargo, un relato romántico que «constituye una auténtica poesía en prosa» (García Viñó, 1970: 257) y que marca un contrapunto divergente con el legado temático antedicho. Se hace referencia a «La Creación», fechado por su autor, Gustavo Adolfo Bécquer, en 1861. En este escrito, subtitulado «Poema indio», y que vio la luz en la revista El contemporáneo el 6 de junio de dicho año, se recrea el origen del universo a partir de la mitología hindú. En el enfoque recreador del poeta prima un ludismo creativo muy manifiesto, atribuyéndose el principio de las cosas al juego caprichoso de unos niños (Bécquer, 1974: 28). No obstante, bajo el esquema paródico por el que discurre la narración, «se transluce un pensamiento bastante pesimista...» (Montalvo Aponte, 1995: 245) acerca de la duración del mundo.

Y no será ésta la perspectiva de Jorge Guillén en «Creador y creación», sino la de tratar de adentrarse en el imaginario de una leyenda hinduista que le sedujo sobre otras para recrearla desde dentro, no para distanciarse de ella valiéndose de un tratamiento lúdico. A Bécquer se debe el hito de inaugurar en la literatura española, recreándolo, el mito hindú que cuenta el comienzo de cualesquiera orbes. Lo hizo mediante una narración teñida de humorismo, la cual «solamente podría transcribir hoy, con fidelidad, el milagroso hallazgo del dibujo animado» (Berenguer Carisomo, 1974: 31).

Pionero en inspirarse en una creencia hindú para confeccionar una composición poética contemporánea sobre sobre el asunto de referencia, en la elaboración de «Creador y creación» se 
emplearía Jorge Guillén en dos períodos temporales, realizando su texto en dos ciudades distintas. En efecto, en París iba a comenzarlo en los días 29 y 30 de junio de 1971, terminándolo en Cambridge, en Massachusetts, el 12 de octubre de 1972 (Guillén, 2008: 1593). La composición está dedicada a Raimundo Panikkar (1918-2010), filósofo, teólogo y escritor barcelonés en cuyo dilatado currículo figura que enseñó en Harvard, institución universitaria establecida en la localidad antecitada de Cambridge, en el Estado de Massachusetts, entre 1971 y 1978, años después de que el escritor vallisoletano lo hiciese en ese mismo centro estadounidense.

Acaso la circunstancia de estar vinculados ambos, Guillén y Panikkar, a Harvard, fuese un pretexto para la dedicatoria del poema, pero hubo tal vez otros dos relacionables con el contenido mismo del texto. Uno pudo ser que «Creador y creación» se inspira en una leyenda genesíaca de una cultura enraizada en la vida del pensador catalano-hindú. Y otra todavía acaso fuese que ese intelectual catalán se distinguió por su conocimiento profundo de la India y por establecer lazos de teología comparada entre hinduismo y cristianismo, aspecto éste en el que incide el poema del vallisoletano.

Bajo el título de la composición consta una brevísima cita, la frase «El germen de oro aparece», la cual remite, conforme indica el autor, al Rig-Veda 7, 7, II. Recordemos, antes de nada, que Rig$V e d a$ es el nombre que se da al más lejano texto de la India, creyéndose compuesto en el siglo XV a. C., y, por tanto, de los libros hindúes conocidos como Vedas, sería el más antiguo. Consta de una colección de 1028 himnos que suman un total de 10552 versos. La obra fue escrita en el lenguaje del que se originaría el sánscrito. En los Vedas se manifiestan las «visiones» de unos videntes que se tuvieron por sagrados. Respecto a la citación del poeta que se mencionó un poco más arriba, referiré que se hace eco de una leyenda de la creación del universo según la cual Brhama depositó una semilla en el agua, semilla que más tarde se convertiría en un huevo de oro.

Poema de cincuenta versos y elaborado en heptasílabos y líneas de once, exceptuando dos de ellas, trisilábicas, «Creador y Creación» se organizó como silva. Su contenido cabría dividirlo en dos partes, a las que acaso se aluda en el poema mismo cuando en el verso 30 leemos: « la segunda etapa da principio» (Ídem, 831). La creación del mundo es imaginada, por tanto, en dos etapas, aunque en cada una de ellas cabría señalar fases internas, como luego iremos explicando.

Como preanuncia su título, en el poema imagina Jorge Guillén cómo pudo acontecer la creación del mundo, pero basándose en una leyenda concreta del hinduismo, y eligiéndola entre otras varias versiones. Expondré de modo sucinto, y como ejemplo, dos de las leyendas desestimadas.

Una de ellas cuenta cómo Brahma, también mencionado como Prajapati, o Señor del Linaje, se creó a sí mismo y después crearía a Sarasvati, la Tierra. Enamorado de su propia hija, ella rehuyó mantener relaciones sexuales con su progenitor, transformándose en vaca. Entonces él lo haría en toro, y de la cópula entre ambos iba a nacer un ternero. Las demás criaturas se fueron creando de manera similar. Serasvati se transformaba en un animal, y quien le había dado el ser se convertía en su contraparte masculina creando la correspondiente descendencia (Hemenway, 1988: 57). 
Otra leyenda narra que, habiendo aparecido de modo espontáneo el Ser eterno e incomprensible que solo puede percibirse espiritualmente, de él surgiría Brahma, padre común de los mundos todos. De su misma sustancia nació una mujer, Sarasvati, de la que se enamoró. Le propuso engendrar a todas las criaturas del universo mediante un transporte amoroso inmenso. La diosa aceptó, y ambos se retiraron a un lugar secreto para realizar su mutuo deseo. Cien años divinos se prolongaría ese transporte amatorio, amplísimo período temporal que vale por muchos millones de años humanos (García Font, 1988: 57). Pero este par de leyendas pudieron parecerle a Jorge Guillén menos atractivas que aquella por la que se decantó, y reinterpretó, como a partir de ahora glosaré.

Frente a quienes han creído y propagado que la nada está en el origen de cuanto existiría después, el poema se abre aseverando que en el principio, por no haber, no existiría «ni siquiera la gran Nada», concepto éste cuya inmensidad se pondera escribiéndolo en mayúscula. Siendo el espacio y el tiempo entidades menores que dicha Nada, excusado será añadir que tampoco existían. Lo aparentemente paradójico, sin embargo, es que el no existir era un ente que sí existía, o en otras palabras: el no ser sí era, aunque «sumido en su vacío», añade el narrador apelando a un concepto de gran predicamento en el budismo.

Pero el no ser decidió ser, y se crearía a si mismo con el mero murmurar «Que yo sea», y fue. Ese ser sería el Uno, palabra en el texto con mayúscula. Y ese Uno, ese ser completo, era Prajapati. Completo, aunque en absoluta soledad, y sin conciencia. Solo adquiriría la conciencia cuando se percató de que existía al exclamar su autodescubrimiento y decir «¡Yo soy!» (Ídem, 830).

Su única compañía era él, y de esa soledad nacieron sus dos primeros sentimientos, porque sufría y estaba temeroso, sin que pueda darse razón de la causa, dado que nada existía sino él. Y no tardó en sentir también Deseo, tercera palabra señalada en mayúscula por el poeta. ¿Cómo iba a satisfacerlo? Lo satisfizo creando, en un crear que no era sino repartirse en otros mediante su autosacrificio, al que se ofrendó como víctima, como leemos en el texto guilleniano:

Todo está siendo junto:

El sacrificador, el sacrificio,

El tan sacrificado.

No había más que un solo Prajapati (Ibídem).

En los versos citados el relato del cristianismo puede venir a la mente de los lectores, pretendiéndolo así alta probabilidad el autor, acaso para señalar parecidos esenciales entre relatos míticos de distintas religiones. Más adelante, como veremos, volverán a establecerse otras similitudes entre hinduismo y creencia cristiana a vueltas del pretexto del incesto en el que se situaría el origen de la especie humana, y a propósito también del amor divino que crea, redime y diseña el retorno de las criaturas al seno de quien quiso darles vida. Pero prosigamos dando cuenta de cómo continúa el poema.

Repartiéndose fueron naciendo las criaturas, de ahí que Prajapati anide en el interior de todas y de cada una, aunque de modo singular en las dotadas de conciencia. Esparcidas éstas en el caos, luchaban entre ellas en medio de la confusión, y temieron a quien las había engendrado. Siendo así, 
ya «Hay mundo» (Ídem, 831) sintetiza el narrador poemático, señalando de este modo que la etapa primera de la Creación ya había culminado.

Habiendo originado criaturas, consecuentemente el Uno es el Padre común de todas. Una de ellas era de gran belleza, la Aurora, llamada Dyasus, a la cual, en el Rig-Veda, se le dedican alrededor de una veintena de himnos. Su nombre significa «La esplendorosa». Su entidad es plural, porque las auroras son múltiples. Dyasus permanece joven siempre, a diferencia de los seres humanos, que envejecen al acusar el paso del tiempo (García Font, 1988: 30 y ss.). Con ella generó vida Prajapati a otros seres, comenzando la etapa segunda de la Creación. Los engendró cometiendo incesto, pues se trataba de su propia hija la que los fue dando a luz.

El concepto de incesto reaparece en $Y$ otros poemas en el texto que sigue a «Creador y Creación», y que lleva por título «Sucesos de jardín». En él se inspira el poeta en el relato mítico del Génesis relativo a cómo fue creado Adán en el Paraíso terrenal y cómo después fue naciendo la especie humana. En los versos de la composición se enfoca un doble incesto en el origen de la Humanidad. Un incesto primero sería el que originó la creación del hombre, porque su padre habría sido Dios y su madre la Tierra, previamente creada por Dios. La semejanza de lo antedicho con el mito de Prajapati y Dyasus salta a la vista, aun cuando en el mito cristiano, a diferencia del hindú, no intervenga la figura del Deseo erótico en la creación adánica. Y de un incesto posterior nacería la saga de los seres humanos. Porque Adán es padre y esposo a la vez de Eva, engendrando a sus hijos con su propia hija. "Sucesos de jardín" concluye así:

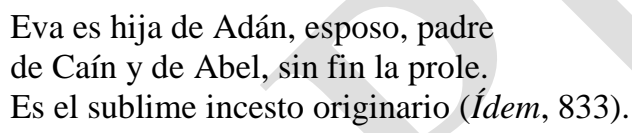

El principio de la historia humana habría nacido, por ende, de acuerdo con las concepciones hindú y cristiana recreadas y reinterpretadas por Jorge Guillén, de un incesto, aunque ocasionado por el sentimiento del amor, de un amor salvífico. Aquel incesto primigenio salva, por tanto, aquel incesto redime. Dios crea y salva a quienes creó, que así retornan a Prajapati, de modo y que «Todo será divino» (Ídem, 831).

Este retorno a una divinidad muy abstracta también se contempla en las creencias expuestas en el Libro del Tao chino, donde se enseña que todas las cosas regresan al Tao y se juntan como en una red sin que ninguna quede fuera de ella. (HOOPER, 2013: 59) Ni en la concepción hindú, ni en la reflejada en el Tao, hay, sin embargo, mediador, a diferencia del que concibe la teología cristiana valiéndose de la Encarnación de Jesucristo. Ningún hombre tiene esa prerrogativa de dividirse al crear a otros y amarlos en virtud de ese crear. El poema finaliza, a modo de conclusión sintética, señalando que

El creador se parte, crea mundo,

Ama a sus criaturas,

A la divinidad unidas -y divinas,

Buenas así, y salvadas de su caos

Por Prajapati, Padre.

No hay mundo sin amor (Ibídem). 


\section{Dos perspectivas diferenciadas}

Hemos podido constatar dos perspectivas dispares en la plasmación del plural sentimiento del amor en distintos poemas de Octavio Paz y de Jorge Guillén. En los textos comentados, que fueron compuestos en fechas próximas, en la mitad segunda de la década de los sesenta, ambos poetas evitaron acudir a estímulos mitológicos occidentales, acudiendo a la mitología del hinduismo para expresar sus respectivos prismas de enfoque. Partiendo de un episodio anecdótico que le acaeció en la India, el de constatar el nulo respeto a unas imágenes, para sus fieles, pero también para él, tan preciadas, las de Shiva y Sarasvati, el escritor azteca se basaría en la legendaria historia de Shiva para profundizar en el hondo y especial sentido del ligamen amoroso que le unía a su esposa Marie José. Esa profundización la realizó mostrando y explorando en el poema «Domingo en la isla de Elefanta» la hondura de sus propias vivencias sentimentales.

En Jorge Guillén los pretextos mitográficos hindúes se poetizan desde la relativa distancia que les otorga el hecho de circunscribirlos al universo literario, recreándose de manera lírica, en Homenaje. Reunión de vidas, el sentir amoroso desde escenas voluptuosas del Gita Govinda, en las que pudo expresar también su experiencia personal, toda vez que para el escritor vallisoletano la lectura honda de los versos ajenos implicaba asumirlos.

Diferenciada fue su perspectiva en $Y$ otros poemas, porque los versos de «Creador y creación» recrean, por cauces narrativos, el origen del cosmos y de sus seres partiendo de una versión muy poética del mito genesíaco inspirada en el Rig-Veda, y que plasma la llamativa constatación de que gracias al incesto nació la Humanidad, y en su virtud su redención salvífica no hubiera podido producirse sin ese incesto primigenio. Al desarrollar la argumentación de este poema, Jorge Guillén señala convergencias entre el mito del origen entre la cosmovisión hindú y la cristiana merced a prismas propios de lectura que se adentran en el ámbito de las religiones comparadas.

\section{Referencias bibliográficas}

BÉCQUER, G.A. (1974): Leyendas, apólogos y otros relatos. Ed. de Rubén Benítez. Barcelona, Textos Hispánicos Modernos 27, Editorial Labor.

Berenguer CARISOMO, A. (1974): La prosa de Bécquer. Sevilla, Universidad de Sevilla. (Segunda edición corregida y aumentada).

BLASCO IBÁÑEZ, V. (1967). Obras completas. Madrid, Aguilar, vol. III.

DurÁn, M. (1982): «La huella de Oriente en la poesía de Octavio Paz», en VV.AA., Octavio Paz. Edición de Pere Gimferrer. Madrid, Persiles 133, El escritor y la crítica, Taurus.

GARcíA-Font, J. (1988): Dioses, ideas y símbolos de la India. Hospitalet de Llobregat, Ediciones Fausí.

GARCÍA-ViÑó, M. (1970): Mundo y trasmundo en las leyendas de Bécquer. Madrid Campo Abierto, 29, Gredos. 
GuILlÉn, J. (2008): Aire nuestro. Homenaje. Y otros poemas. Edición crítica de Óscar Barrero Pérez. Barcelona, Tusquets.

Hemenway, P. (2006): Dioses hindúes. Hilversum, Texcase.

Hooper, R. (2013): Jesús, Buddha, Krishna \& Lao Tzu. The parallel Sayins. New York, Bristol Park Books.

MontAlvo APONTE (1995): «Sublimación e irrisión en las narraciones orientales de Bécquer», en VV.AA., Bécquer. Origen y estética de la modernidad. Edición dirigida por Cristóbal Cuevas García y coordinada por Enrique Baena. Málaga, Publicaciones del Congreso de Literatura Española Contemporánea, pp. 241-249.

Nivedita, S. - CoOmaras, AK. (1995): Hindúes y budistas. Madrid, M. E. Editores.

PAMBERTON, J. (2015): Myths \& Legens. New York, Chartwell Books.

PAZ, O. (1998): Ladera Este seguido de Hacia el comienzo y Blanco. Barcelona, Galaxia Gutemberg.

PHILliPS, Rachel (1976): Las estaciones poéticas de Octavio Paz. México, Fondo de Cultura Económica.

Renou, L. (1951): Les Littératures de l'Inde. Paris, Presses Universitaires de France.

Vizoso, P-J. (1998): «Perfil literario de Octavio Paz», Calas. Revista de Literatura del Centro Cultural Generación del 27, 3 (junio), pp. 58-69.

Wilkinson, Ph. (2008): Religions. New York, Metro Books.

YUDIN, Florence L. (1991): «From Synthesis to Continuity: Jorge Guillén's Y otros poemas», en VV.AA., Jorge Guillén. Aire Nuestro. Una poética afirmativa de las maravillas de la cotidianidad, Anthropos, pp. 91-97. 